\title{
A New Trombiculid Mite of the Genus Doloisia from Kagoshima and Oita Prefectures, Japan (Prostigmata: Trombiculidae)
}

\author{
Hiroshi SUZUKI ${ }^{1}$, Susumu YAMAMOTO ${ }^{2}$ and Shinichi NODA ${ }^{3}$ \\ ${ }^{1}$ Research Center for Tropical Infectious Diseases, Institute of Tropical Medicine, Nagasaki \\ University, Sakamoto 1-12-4, Nagasaki 852-8523, Japan \\ ${ }^{2}$ Department of Hygiene, Faculty of Medicine, Kagoshima University, Sakuragaoka, \\ Kagoshima 890-8520, Japan \\ ${ }^{3}$ Research Center for the Pacific Islands, Kagoshima University, Korimoto, Kagoshima \\ 890-8580, Japan
}

(Received 26 May 2003; Accepted 8 September 2003)

\begin{abstract}
A new species of trombiculid mite, Doloisia uchikawai sp. nov., collected in Kagoshima and Oita Prefectures, Japan, is reported here with their morophological characteristics. It is closely related to D. okabei Sasa et al., 1952 and D. minamii Suzuki 1976, but distinguishable in the shape of scutum, sensillae, number of coxal setae and in standard measurements of scutum.
\end{abstract}

Key words: Trombiculid mite, Doloisia, new species, Kagoshima and Oita Prefectures

\section{INTRODUCTION}

A new species of mites sampled in Kagoshima and Oita prefectures, is morphologically classified as a members of Genus Doloisia Oudemans, 1910 among the tribe Schongastiini, by expanded sensillae, multiple coxalae more than two, and palpotarsal formula (fT)=4B.S. There are four species of Doloisia distributed in Japan: D. okabei Sasa, Hayashi, Kawashima, Mitsutomi et Egashira, 1952; D. minamii Suzuki, 1976; D. satoiana Suzuki, 1976 and D. zentokii Suzuki, 1976. This new species differs from these four species in the following points: shape of palpal formula and sensillae, shape and dimensions of scutum, and number of coxalae and dorsal setae.

\section{Doloisia uchikawai Suzuki, Yamamoto et Noda, n. sp. (Figs. A-G)}

Morphology of larva: This species closely resembles D. okabei Sasa et al., 1952, but is morphologically different in the pentagonal shape of scutum, globose appearance of sensillae and number of coxal setae in coxae III, and in standard measurements of scutum. It also somewhat resembles to D. minamii Suzuki, 1976, but different in the morphology of globose senillae, number of coxal setae and long mastifemorala on leg 2, and in standard measurement of scutum. In comparison with other species of Doloisia distributed in China (Wen, T., 1984 and Li Jiacan, 1997), South East Asia (Audy and Nadchatram, 1957, Nadchatram, 1970, Yunker and Brennan, 1962), it is different in one or more of the following characters: palpal formula, shape of scutum and sensillae, number of coxal setae and number of dorsal 

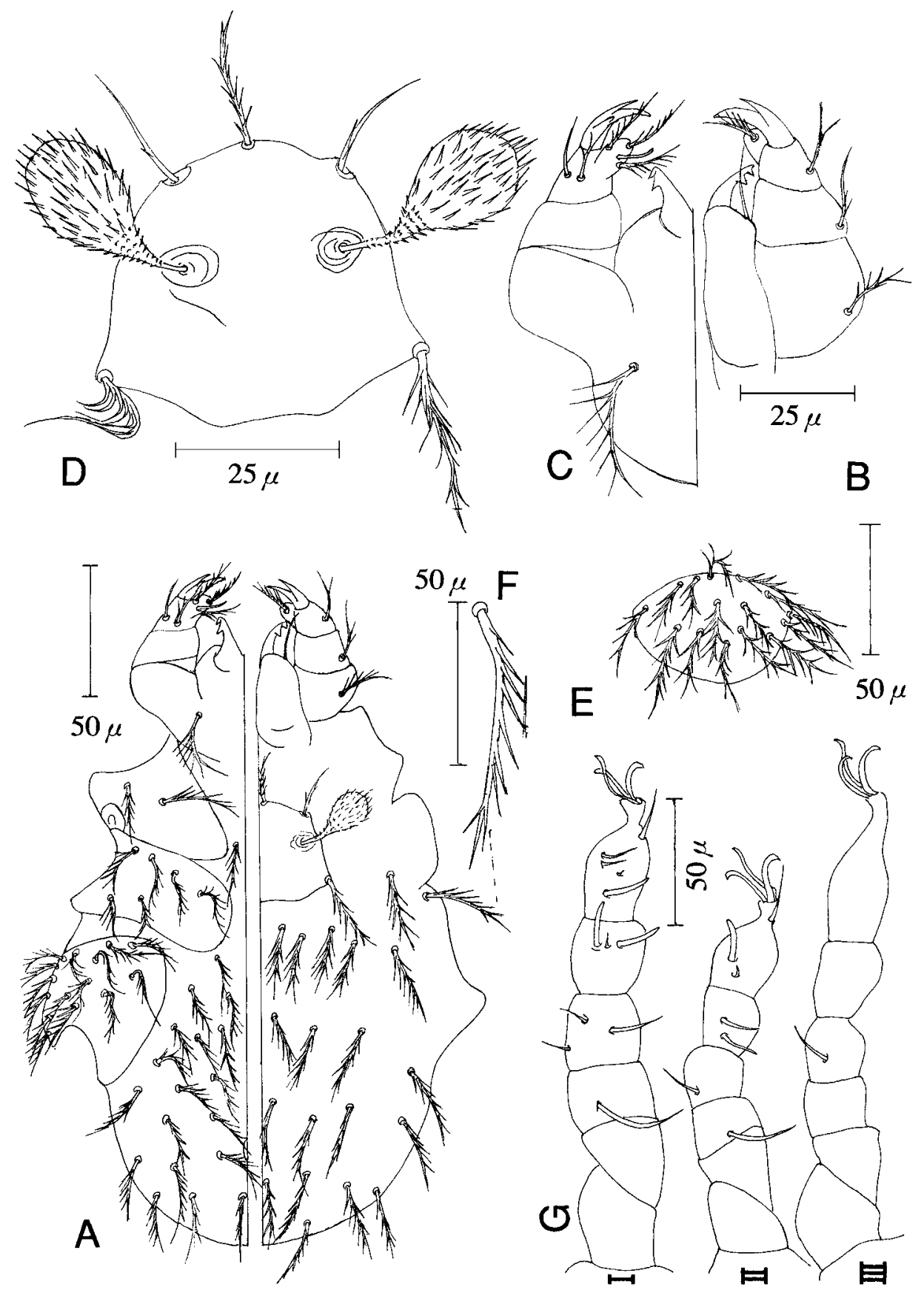

Figs. A-G. Doloisia uchikawai n. sp., Larva. (A) Unengorged larva, left ventral, right dorsal; (B) gnathosome, dorsal; (C) gnathosome, ventral; (D) scutum; (E) coxa III; (F) humeral seta; and (G) leg with specialized setae. 
Table. Standard measurements of Doloisia uchikawai n. sp. (in micra).

\begin{tabular}{lccccccccccccccccc}
\hline & AW & PW & SB & AP & ASB & PSB & SD & am & al & pl & s & As & PS & pp-ss & hm & dsp & vsa \\
\hline Range (n=15) & 20 & 50 & 20 & 30 & 18 & 18 & 36 & 28 & 18 & 39 & 33 & 15 & 15 & +13 & 40 & 38 & 35 \\
& 1 & 1 & 1 & 1 & 1 & 1 & 1 & 1 & 1 & 1 & 1 & & 1 & 1 & 1 & 1 & 1 \\
\multirow{2}{*}{ Mean } & 23 & 58 & 25 & 35 & 23 & 20 & 41 & 30 & 20 & 45 & 40 & & 18 & +18 & 45 & 45 & 38 \\
& 21 & 55 & 22 & 32 & 22 & 18 & 38 & 30 & 19 & 41 & 36 & 15 & 17 & +15 & 43 & 40 & 36 \\
\hline
\end{tabular}

setae, specialized setae on legs and standard measurements.

Body color was milky white. The size was very small: the body length and width 196 (190-200) $\mu \mathrm{m} \times 137(120-140) \mu \mathrm{m}$, respectively, in an unengorged condition of larvae $(\mathrm{n}=15)$.

Palpal formula $\mathrm{B} / \mathrm{b} / \mathrm{bNb}+4 \mathrm{~B} \cdot \mathrm{S}$, eyes very small $1+1$ but half of the specimens have no eyes. Galeal seta nude, scutum as figured (Fig. D) roughly pentagonal, broader behind than in front. Convexity of antherior margin especially in midline, posterior margin biconcave.

Sensillae globose based located in antherior to the level of posterolateral setae, Am barbed, al only one barbed or nude, pl setae well barbed and longer than other usual scutal setae.

\section{Scutal measurements are shown in Table.}

Fifteen specimens used for measurements.

Dorsal setae total 40-48, arranged 4-10(14)-8(10)-8(10)-8-2.

Ventral setae total 36-40, 2 pairs of sternal setae. Coxal setae 2(3)-4(6)-10(14).

Specialized setae on legs as in Fig. G.

Leg I: Length of leg $200(190-220) \mu \mathrm{m}$. Length of tarsus 45 (43-48) $\mu \mathrm{m}$ : a long mastifemorala, 2 genualae, 1 microgenuala, 2 tibial spurs, 1 microtibiala, 1 pretarsala, 1 suberminala, 1 parasubterminala, 1 tarsal spur, 1 microtarsala. Leg II: Length of leg 182 (170-190) $\mu \mathrm{m}$. Length of tarsus $37(35-38) \mu \mathrm{m}$ : a long mastifemorala $(25 \mu \mathrm{m})$ peculiarity of this species, 1 genualae, 1 tibial spurs, 1 tibiala, 1 pretarsala, 1 tarsal spur, 1 microtarsala. Leg III: Length of leg $212(210-230) \mu \mathrm{m}$. Length of tarsus 50 (45-53) $\mu \mathrm{m}$ : 1 genualae.

These specimens were collected from soil samples in Kagoshima and Oita Prefectures using Tullgren apparatus.

Host: unknown.

Terminology follows Vercammen-Grandjean (1968) and Sasa (1956)

Etymology. The specific name is dedicated to Dr. Kimito Uchikawa who has contributed greatly to the knowledge of Acarology.

Materials examined. One specimen 17-XI-1995, Yuwakawa, Osumi-Gun, Kagoshima, Japan. S. Yamamoto and S. Noda. Seven specimens 11-III-1997, Wakimoto, Aira-Cho, Aira-Gun, Kagoshima, Japan. S. Yamamoto and S. Noda. Two specimens 25-V-1997. Idaigaoka, Hasama-Cho, Oita-Gun, Oita, Japan, H. Takaoka and Xuan Da Pham. Four specimens 21-X-1997. Same palce and collectors.

Holotype (NSMT-Ac 11682) and 10 paratypes (NSMT-Ac 11683-11693) will be deposited at the National Science Museum, Tokyo, Japan.

\section{ACKNOWLEDGEMENTS}

We would like to express our sincere thanks to Dr. Kimito Uchikawa for his valuable 
suggestions. Thanks also to Drs. Hiroyuki Takaoka and Xuan Da Pham who kindly supplied us valuable materials sampled in Oita Prefecture.

\section{REFERENCES}

Audy, J. R. and M. Nadchatram (1957): Malaysian parasites XXVI. New intranasal species of Traubacarus n. gen. (Acarina, Trombiculidae). Stud. Inst. Med. Res. Malaya, 28: 187-230.

Domrow, R. and N. Nadchatram (1962): Three new species of Doloisia from S. E. Asia (Acarina, Trombiculidae). Acarologia, 4: 577-585.

Li, Jiacan (1997): Trobiculid mites of China—Studies on Vector and Pathogen of Tsutsugamushi disease (ed., Li Jiacan) pp. 330-349, Huayu Nature Book Trade Co. Ltd., Beijing, China. 570 pp.

Nadchatram, M. (1970): A review of intranasal chiggers with descriptions of twelve species from East New Guinea (Acarina, Trombiculidae). J. Med. Entomol., 7(1): 1-29.

Pham, X. D., H. Suzuki and H. Takaoka (2001): Distribution of unengorged larvae of Leptotrombidium pallidum and other species in and around the rodent nest holes. Southeast Asian J. Trop. Med. Public Health, 32(3): 553557.

Sasa, M. (1956): Tsutugamushi and Tsutsugamushi disease. 479 pp. Igaku Shoin, Tokyo. (In Japanese)

Suzuki, H. (1976): Reports of medico-zoological investigations in the Nansei Islands. Part IV. Three new trombiculid mites of the genus Doloisia from the Amami Island (Prostigmata: Trombiculidae). Jap. J. Sant. Zool., 27(3): 265-270. (In Japanese)

Vercammen-Grandjean, P. H. (1968): The chigger mite of the Far East. 135 pp, Special Study U.S. Army Med. Res. And Devel. Comm. Wash. D. C. 20315. USA.

Yunker, C. E. and J. M. Brennan (1962): Endoparasitic chiggers: II. Rediscovery of Doloisia synoti Oudemans, 1910, with descriptions of new subgenus and two new species (Acarina: Trombiculidae). Acarologia, 4: 570576.

Wen, T. (1984): Sand mite of China (Acariformes: Trombiculidae \& Leewenhoekiidae). 370 pp, Xue Lin Publishing House. Shanghai, China.

摘 要

Doloisia 属ツツガムシの 1 新種の記載 鈴木 博（長崎大学熱帯医学研究所熱帯感染症研 究センター), 山本 進 (鹿児島大学医学部衛生学講座), 野田伸一 (鹿児島大学多島圈研究 センター)

鹿児島と大分県で土壤サンプルより得られた Doloisia 属のッッガムシ Doloisia uchikawai Suzuki, Yamamoto et Noda sp. nov. を記載した.

本種は D. okabei Sasa et al., 1952 に似るが，背甲板の形が亜五角形で，感覚毛が球状，第 2 脚と 3 脚の基節毛が少ない点などで容易に区別される.

また，他の一種 D. minamii Suzuki, 1976 にも似るが，感覚毛が球状，第 1 脚基節毛の数が 少なく, 第 2,3 脚基節毛の数が多い点, 第 2 脚腿節に 1 本の単条長毛を持つことで区別される. 